\title{
Intercropping of chick pea and mustard on control of botrytis grey mold in western Terai, Nepal
}

\author{
R Khadka $^{1}, \mathrm{~S} \mathrm{Joshi}^{2}$ and RB Chaudhary ${ }^{1}$ \\ Regional Agricultural Research Station, Khajura, Banke, NARC, Nepal \\ Plant pathology Division, Khumaltal, Lalitpur, NARC, Nepal
}

\begin{abstract}
Integrated management strategies are required to minimize botrytis grey mold disease of chickpea (CICER ARIETINUM L.) caused by Botrytis cineria. This study was undertaken to determine the effect of cultivars and seed ratio in chickpea-mustard intercropping system on the severity of botrytis grey mold. Three chickpea varieties Abarodhi, KGP59 and ICCCV 97207 were intercropped with Bikash variety of mustard in different combinations. These two crops were grown at RARS, Khajura in three replications in 2012 at the ratio of sole chickpea, 3.1 ICCV97207.Bikash, 3.1 KPG-59.Bikash, 2.1 KPG59.Bikash, 2.1 ICCV-97207.Bikash,2.2 ICCV97207.Bikash, 2.2 KPG59.Bikash,1.2 ICCV97207.Bikash, and 1.2 KPG 59.Bikash. Among the three tested varieties, highest disease score and AUDPC was recorded in Abarodhi (7.00, 0.83), followed by KPG59 $(6.444,0.79)$, and lowest in ICCV97207 $(4.77,0.58)$. Similarly in sole cropping, highest yield per plant was found in KPG59 (5.47g), followed by ICCCV9720 (4.46 g) and Abarodhi (3.46 g). Among the tested intercropping system, lowest disease incidence was recorded in 1.2 ICCV97207. Bikas followed by 1.2 KPG59. Bikash. From this research, it can be suggested that intercropping chickpea with mustard can significantly reduce BG of chickpea and thus it could be developed into an environment-friendly cropping system for BG control in chickpea fields. The combination, in which disease incidence was lowest, can be replicated in the areas where BG is a major constraint in chickpea production.
\end{abstract}

Key words : cicer arietinum, Botrytis cinerea, seed ratio, disease severity, and AUDPC

\section{Introduction}

Chickpea (Cicer arietinum L.) is one of the most important pulse crops of Nepal. The area and production of chickpea has been declining since last decade. According to ABPSD (2012), the area of chickpea was reduced from 14,308 ha to 9124 ha and production from 12,148 to 8,130 t from 2001 to 2010. The main cause of this decline is the flower drop and no pod formation problem (Chaurasiya and Joshi, 2004). Flower drop is mainly attributed to the attack of botrytis grey mold (Botrytis cinera Pers Ex.Fr) (Chaurasiya and Joshi, 2004). However, some workers also indicated that flower drop occurs due to the deficiency of boron, which cause to abort chickpea flowers (Shrivastav et al. 1996).

Botrytis gray mold (BG) caused by Botrytis cinerea Pers. ex. Fr., appeared as one of the most devastating diseases of chickpea, which may cause $100 \%$ yield loss. This disease was first reported in 1981 in Bangladesh (Ahmed et al, 1981) and now become the second largest problem of chickpea production after Aschochtyta blight around the globe (Nene et al., 1996). The disease severity increases and complete yield loss may occur in those years, in which winter is extensively wet and humid (Reddy et al., 1988; Pande et al., 2002). This disease is seed, soil and air borne. 
Preventive measures, such as low seed rate, chemical spray, wider row spacing helps to reduce the disease. Beside them the use of resistance varieties is most economical way of controlling the disease. However, most of the varieties grown by farmers are susceptible to this disease. Varietal screening to identify sources of BG resistance was initiated in 1984 in Nepal. However, changes in disease reaction of several chickpea lines over seasons and location have made the breeding task for botrytis resistance difficult (Karki et. al. 1989). The level of resistance/ tolerance is very low in the identified genotypes, and the chemical control of the disease in not economical. Therefore, the control of this disease through holistic approach of agronomical manipulations and use of resistance genotype was considered appropriate. Researchers claimed that resistant cultivars and intercropping offer the best solution to control the disease. Therefore, the focus of this study is to assess the response of intercropping and varieties in minimizing the BG infestation in mid western Terai of Nepal.

\section{Materials and methods}

A field experiment was carried out at Regional Agricultural Research Station, Khajura in 2012/13 to find out the suitable intercropping system for higher profitability by managing BG below the economic threshold level. The purpose of this experiment was also to find out the response of different pipeline varieties on this devastating disease. Randomized complete block design (RCBD) was used in this experiment. Three varieties of chickpea; Abarodhi, KPG 59 and ICCV97207 were intercropped with Bikash variety of Toria in plot size of $5 \mathrm{~m} \times 3 \mathrm{~m}$. Treatment combinations in the experiment were; Sole KPG59, Sole ICCV97207, Sole Abrodhi, 3.1 row ratio of ICCV97207 and Bikash, 3.1 row ratio of KPG-59 and Bikash, 2.1 row ratio of KPG 59 and Bikash, 2.1 row ratio of ICCV-97207 and Bikash, 2.2 row ratio of ICCV97207 and Bikash, 2.2 row ratio of KPG-59 and Bikash, 1.2 row ratio of ICCV97207 and Bikash and 1.2 row ratio of KPG 59 and Bikash. This experiment was carried out in three replications. Recommended fertilizer dose @ 20.40.20 kg NPK per hectare was applied in this experiment. Row and plant spacing was $40 \mathrm{~cm} \times 10 \mathrm{~cm}$.

RARS, Nepalgunj is located at $28^{\circ} 06^{\prime \prime}$ north latitude and $81^{\circ} 37^{\prime \prime}$ east longitude. The altitude of research site is 181 meters above mean sea level. Average annual rainfall of the station is 1000-1500 $\mathrm{mm}$. The average maximum and minimum temperature at the station is $46^{\circ} \mathrm{C}$ and $5.4^{\circ} \mathrm{C}$ respectively. The relative humidity of this place ranges from 27 to $94 \%$. The soil of the experimental plot was sandy to silty loam, poor in organic carbon and available nitrogen, but medium in available phosphorus and potassium. The soil $\mathrm{pH}$ varies from 7.2-7.5.

Botrytis gray mold of chickpea was scored on a 1-9 scoring scale as described by Singh (1999). The interpretation of the scales was as follows. $1=$ immune or Asymptomatic (I), $2-3=$ highly resistant (HR), 4-5 = resistant (R), 6-7 = susceptible (S) and 8-9 = highly susceptible (HS). After the appearance of the disease, it was scored three times at one week interval on whole plot basis. Area under the disease progress curve (AUDPC) was calculated by the method used earlier by Shaner and Finney (1977). Data analysis was done in Microsoft Excel (2007) and MSTAT-C (1986). Data were subjected to analysis of variance (ANOVA) tests. When significant differences were found, means were separated and assessed using Duncan's Multiple Range Test (DMRT). AUDPC was regressed against grain yield (Gomez and Gomez, 1984). 


\section{Results and discussion}

Yield per plant, average disease score of three consecutive dates 18 March, 26 March, and 4 April 2013, and AUDPC were recorded from the treatments of chickpea and mustard intercropping. The recorded data are presented in Table 1.

Table 1. Yield per plant, average score of three different dates and AUDPC of BG in chickpea in different combinations of chick pea - mustard intercropping at RARS, Khajura in 2012/13

\begin{tabular}{lllll}
\hline Treatments & $\begin{array}{l}\text { Yield per } \\
\text { plant (g) }\end{array}$ & $\begin{array}{l}\text { score }{ }^{\mathbf{0 - 9}} \text { Scale) } \\
\text { Sole KPG59 }\end{array}$ & $\begin{array}{l}\text { AUDPC†† } \\
\text { at March } \\
\mathbf{2 6}\end{array}$ & $\begin{array}{l}\text { AUDPC at } \\
\text { April 4 }\end{array}$ \\
\hline Sole ICCV97207 & $5.47^{\mathrm{abc}}$ & $6.444^{\mathrm{ab}}$ & $0.79^{\mathrm{ab}}$ & $0.90^{\mathrm{ab}}$ \\
Sole Abrodhi & $4.46^{\mathrm{bcd}}$ & $4.77^{\mathrm{abc}}$ & $0.58^{\mathrm{abc}}$ & $0.66^{\mathrm{ab}}$ \\
3.1 ICCV97207.Bikash & $3.46^{\mathrm{cd}}$ & $7.00^{\mathrm{a}}$ & $0.83^{\mathrm{a}}$ & $1.04^{\mathrm{a}}$ \\
3.1 KPG-59.Bikash & $5.98^{\mathrm{abc}}$ & $4.11^{\mathrm{abc}}$ & $0.47^{\mathrm{abc}}$ & $0.57^{\mathrm{ab}}$ \\
2.1 KPG 59.Bikash & $3.93^{\mathrm{bcd}}$ & $5.66^{\mathrm{abc}}$ & $0.68^{\mathrm{abc}}$ & $0.80^{\mathrm{ab}}$ \\
2.1 ICCV-97207.Bikash & $5.77^{\mathrm{abc}}$ & $5.22^{\mathrm{abc}}$ & $0.64^{\mathrm{abc}}$ & $0.66^{\mathrm{ab}}$ \\
2.2 ICCV97207.Bikash & $7.50^{\mathrm{ab}}$ & $4.44^{\mathrm{abc}}$ & $0.56^{\mathrm{abc}}$ & $0.64^{\mathrm{ab}}$ \\
2.2 KPG-59.Bikash & $4.782^{\mathrm{abcd}}$ & $3.88^{\mathrm{abc}}$ & $0.50^{\mathrm{abc}}$ & $0.45^{\mathrm{b}}$ \\
1.2 ICCV97207.Bikash & $4.67^{\mathrm{bcd}}$ & $4.66^{\mathrm{abc}}$ & $0.54^{\mathrm{abc}}$ & $0.61^{\mathrm{ab}}$ \\
1.2 KPG 59.Bikash & $8.299^{\mathrm{a}}$ & $3.00^{\mathrm{c}}$ & $0.33^{\mathrm{c}}$ & $0.40^{\mathrm{b}}$ \\
\hline LSD & $5.71^{\mathrm{abc}}$ & $3.11^{\mathrm{bc}}$ & $0.37^{\mathrm{bc}}$ & $0.42^{\mathrm{b}}$ \\
SEM \pm & $3.17^{*}$ & $2.99^{*}$ & $0.39^{*}$ & $0.48^{*}$ \\
\hline
\end{tabular}

Note. Means within the column followed by the same are not significantly different at $5 \%$ level of significance by DMRT. SEM $=$ Standard Error of Mean, LSD = Least Significant Difference, $\uparrow$ Averages disease scores of three consecutive dates March, 18, March 26 and April 4, 2013. † Area under Disease Progressive Curve.

Among the tested three varieties highest disease score and AUDPC was recorded in Abarodhi (7.00, 0.83), followed by KPG59 (6.444, 0.79), and lowest in ICCV97207 (4.77, 0.58). Similarly in sole cropping, highest yield per plant was found in KPG59 (5.47g), followed by ICCV9720 (4.46 g) and Abarodhi (3.46 g). Among the tested intercropping system, lowest disease incidence was recorded in 1.2 ICCV97207. Bikas, followed by 1.2 KPG59. Bikash. Out of all these treatments, highest yield of chickpea per plant was obtained from 1.2 ICCCV97207. Bikas which was followed by 2.1 ICCV97207. Biaksh.

The results showed that ICCV97207 is comparatively disease resistant in all combinations of chickpea - mustard intercropping. Lowest disease incidence in low seed ratio of chickpea in chickpea mustard intercropping revealed that there is a good potential of growing chick pea intercropped with mustard where BG is major problem.

The response of different varieties with BG was studied by different researchers in the past. Five chickpea lines were found resistant and thirteen moderately resistant among the tested 2505 lines in growth chamber in 1992-1995 by Singh (1997). Similarly, different response of chickpea varieties with BG was also recorded by Hossain et al. (1997) and Pande (1998). The findings of the present 
study revealed that the tested chickpea genotypes showed different types of reaction to BG under field condition. Reddy et al. (1993) reported that Chickpea genotypes with erect and compact growth habit had less BG in comparison to genotypes with bushy and spreading growth habit. The less incidence of BG on compact plant type is attributed to the differences in micro-climatic conditions.

Similarly, low BG incidence in intercropping as compared to sole cropping was due to wider spacing, which reduces humidity in the plant canopy, made by the harvest of mustard crop before the flowering of chickpea. High yield per plant in intercropping as compared to sole cropping is due to the low disease incidence as well as wider spacing and better opportunity to utilize soil moisture and solar radiation. The better yield per plant and lower BG incidence in intercropping system than sole cropping was supported by different researchers in the past. Moore and Ryley (2011) suggested adopting intercropping system to manage the BG in farmers' field. Their suggestion is based on the principle that wider row spacing increases air movement and reduces humidity inside the crop canopy. This reduces the number and duration of infection events of Botrytis. Bakr, et al. (1997) reported that bushy and dense canopy resulting from close spacing and spreading type of plants increases humidity and favors the development of BG.

The results of research conducted in the past coincide and contradict with the result of this research. Reddy et al. (1993) reported that when chickpea was intercropped with linseed in Nepal, a marginal increase in chickpea grain yield was obtained because of low BG incidence and the linseed yield was bonus. However, in contrast to the result of this study Karki et al.(1993) reported no significant difference in BG incidence in sole or intercropping with mustard in Nepal. Bakr et al (1993) reported that chickpea intercropped with linseed showed a reduced incidence of BG in Bangladesh. The lower disease incidence in intercropping system might be due to the creation of wide spacing and low humidity in the plant canopy from the harvest of linseed during main disease attacking period. Chickpea appears to be most susceptible to infection at the flowering stage (Saxena and Johansen 1997). It can be concluded from these discussions that chickpea intercropped with other crops is an integrated management of BG.

\section{Relationship of yield with other traits}

The relationship between yield per plant with plant population, AUDPC and disease scores were worked out for chickpea in chickpea mustard intercropping system. The correlation between plant population, yield per plant, disease average score and average AUDPC of botrytis grey mold is presented in Table 2.

It is evident from the table that there was significant positive correlation between average BG scores and AUDPC, whereas negative correlation between yield per plant and plant population.

Similarly, positive correlation was observed when plant population was regressed against the average disease scores of the BG. It was indicated that $88 \%$ of disease score was contributed by plant population while remaining $12 \%$ was contributed by other factors. Similarly, significantly negative correlation was observed between yield per plant and area under disease progress curve. However, only $21 \%$ variation in the grain yield of chick pea was due to variation in AUDPC under Khajura condition for chickpea mustard intercropping system. Rest of the variation in grain yield was attributed by other factors. 
Table 2. Correlation between plant population, yield per plant, average score and average AUDPC of botrytis grey mold in chickpea in different combinations of mustard chickpea intercropping system at RARS, Khajura in 2012-13

\begin{tabular}{lcccc}
\hline Parameter & Plant Population & Yield per plant & Average score & Av AUDPC \\
\hline Plant Population & 1 & & & \\
Yield per plant & -0.154 & 1 & 1 & \\
Average score & $0.628^{* *}$ & -0.223 & & \\
Av AUDPC & $0.605^{* *}$ & -0.246 & $0.992^{* *}$ & 1 \\
\hline
\end{tabular}

** Correlation is significant at the 0.01 level (2-tailed).

Results of research works conducted in the past are available to compare the findings of this research. Regression analysis was carried out between plant population, yield per plant, average disease score, and average AUDPC and the result of this analysis is presented in Table 3. Khan et al (2010) confirmed that the chick pea yield was greatly influenced by BG score and BG score was influenced by plant population. They found $r$ value 0.73 when chickpea yield regressed against BG score.

Due to an increase in the relative humidity in microclimate within the crop canopy, disease epidemics occur. Singh (1997) showed that the disease increased significantly at high plant population under a dense crop canopy.

Researchers in the past suggested that close correlation between pant density and BG severity is caused by increased relative humidity and leaf wetness in chickpea (Tripathi and Rathi 1992; Butler 1993; Pande et al. 2002).

Table 3. Regression between plant population, yield per plant, average score and Av AUDPC of botrytis grey mold in chickpea in different combination of mustard chick pea intercropping system at RARS, Khajura in 2012-13

\begin{tabular}{lll}
\hline Regression & Equations $(\mathbf{Y}=\mathbf{a}+\mathbf{b x})$ & r value \\
\hline $\begin{array}{l}\text { Disease score against plant population } \\
\begin{array}{l}\text { Yield pear plant }(\mathrm{g}) \text { and Area under disease } \\
\text { progressive curve }\end{array}\end{array}$ & $\mathrm{y}=0.031 \mathrm{x}+0.586$ & $\mathrm{R}^{2}=0.786^{* *}$ \\
Yield per plant $(\mathrm{g})$ and average score & $\mathrm{y}=-0.008 \mathrm{x}+0.603$ & $\mathrm{R}^{2}=0.046$ \\
\hline
\end{tabular}

The findings of this study has been supported by Kandel and Yadav (2008), Pande et al. (2006), Hossain et al. (1997), Bakr, et al. (1997), Butler (1993), Singh and Kapoor (1984), who reported that the chickpea line differed significantly with respect to agronomic traits and yield parameters. Khan (1991), Bakr and Ahmed (1992), Pande and Rao (2000) reported yield reduction of chickpea due to Botrytis gray mold. They recorded yield reduction of chickpea increased with the increasing of Botrytis gray mold disease severity.

Comparing with monoculture, carefully selected intercropping systems are favorable to control diseases without chemicals (Gómez-Rodríguez et al., 2003). It is suitable to be adopted in developing countries, and also has received attention as an approach to sustainable agriculture 
(Yu,1999). The scarcity of genetically resistant resources has brought even more interest in the use of intercropping as a tool for crop disease management (Fernández-Aparicio et al., 2010). There have been many reports about inter- cropping systems which could suppress crop diseases. Yu (1999) found that intercropping with Chinese chive greatly inhibited the occurrence of bacterial wilt in tomato. Gómez-Rodríguez et al.(2003) documented that intercropping with marigold induced a significant reduction in tomato early blight caused by Alternaria solani. Zewde et al. (2007) recorded that garlic intercropped with Brassica spp. could also alleviate white rot of garlic. Ren et al. (2008) addressed that watermelon intercropped with rice in pot experiments could control Fusarium wilt in watermelon. Abdel-Monaim and Abo-Elyousr (2012) also documented that intercropping cumin, anise, onion and garlic could decrease the damping-off and root rot diseases of lentil significantly. Similar to those reports the results presented here demonstrated that chickpea mustard intercropping could suppress BG of chickpea.

\section{Acknowledgments}

The authors are thankful to Man Bahadur Chadaro and Gopi Krishsna Shrestha for collecting data and managing experimental blocks according to the research protocol.

\section{References}

Abdel-Monaim, MF, KAM Abo-Elyousr. 2012. Effect of preceding and intercropping crops on suppression of lentil damping-off and root rot disease in New Valley, Egypt.Crop Prot. 32.41-46.

ABPSD. 2012. Statistical information on Nepalese agriculture. Government of Nepal, Ministry of Agriculture and Co-operatives.

Bakr, MA and F Ahmed.1992. Botrytis gray mold of chickpea in Bangladesh. Pages 10-12 in Botrytis gray mold of chickpea. (eds. MP Haware, DG Faris, and CLL Gowda ). ICRISAT, Patancheru, AP, India.

Bakr, MA and MH Rashid. 2007. Strategic intervention on pulse disease research at BARI. Proceedings of advances in plant pathology research in Bangladesh. Gazipur, 11-12 February, 2007.

Bakr, MA, MM Rahman, F Ahmed, J Kumar.1993. Progress in management of botrytis gray mold of chickpea in Bangladesh. Pages 17-19 in 'Recent advances in research in botrytis gray mold of chickpea'. (eds. MP Haware, CLL Gowda, D McDonald). ICRISAT, Patancheru, AP, India.

Bakr, MA, MS Hossain, and AU Ahmed. 1997. Research on botrytis gray mold of chickpea in Bangladesh. Pages 15-18 in 'Recent advances in research on botrytis gray mold of chickpea'. Summary proceedings of the Third Working Group Meeting to discuss collaborative research on botrytis gray mold of chickpea, in Pantnagar, Uttar Pradesh, India (eds. MP Haware, JM Lenne, and CLL Gowda). ICRISAT, Patancheru, AP, India.

Butler, DR. 1993. How important is crop microclimate in chickpea botrytis gray mold? Pages 7-9 in 'Recent advances in research on botrytis gray mold of chickpea'. (eds. MP Haware, CLL Gowda, D McDonald). ICRISAT, Patancheru, AP, India. 
Chaurasia, P, CP and S Joshi 2004. Management of botrytis gray mold (Botrytis cinerea Pers. Ex. Fr.) of chickpea at Tarahara, Nepal. Nepal Agric. Res. J., Vol. 4 \& 5, 38-41.

Fernández-Aparicio, M, M Amri, M Kharrat, D Rubiales. 2010. Intercropping reduces Mycosphaerellapinodes severity and delays upward progress on the pea plant. Crop Protection 29. 744-750.

Gomez-Rodriguez, O, E Zavaleta-Mejı, VA Gonzalez-Hernandez, M Livera-Munoz, E CardenasSoriano. 2003. Alopathy and microclimatic modification of intercropping with marigold on tomato early blight disease development. Field Crops Research 83. 27-34.

Hossain, MS, M Motiur Rahman, and MA Bakr. 1997. Screening chickpea genotypes for botrytis gray mold resistance in Bangladesh. Pages 33-34 in Recent advances in research on botrytis gray mold of chickpea. summary proceedings of the Third Working Group Meeting to Discuss Collaborative Research on Botrytis Gray Mold of Chickpea, 15-17 Apr 1996. ICRISAT, Patancheru, AP, India.

Kandel, YR and CR Yadav. 2008. The paper presented at the 27th National Winter Crops Workshop (Abstract). Nepal Agricultural Research Council, Khumaltar, Lalitpur, Nepal.

Karki, PB, R Tiwari, O Singh and MP Bharati. 1989. Effect of sowing date on the incidence of botrytis gray mold in chickpea. ICN21, Dec 1989.

Karki, PB, S Joshi, G Chaudhary and RN Chaudhary. 1993. Studies on botrytis gray mold of chickpea in Nepal, page 11-13 in Recent advances in research on botrytis gray mold of chickpea (eds. MP Haware, CLL Gowda, and D McDonald ). ICRISAT, Patancheru, AP, India.

Khan, AR. 1991. Disease management of crops. Pages 1-4 in 'Proceedings of the 4th Biennial Conference of the Bangladesh'. Phytopathological Society, 6-7 February (1991).

Khan, MR, S Ahraf, S Shahid, and A Anwer. 2010. Response of some chickpea cultivars to foliar, seed and soil inoculations with Botrytis cinerea. Phytopathol. Mediterr. 49. 275-286.

Moore, K and M Ryley. 2011. Chickpea disease management in 2011 - Northern region. Industry and Investment NSW, Australia.

Nene, YL, VK Sheila, SB Sharma. 1996. A world list of chickpea and pigeonpea pathogens (5th ed.). ICRISAT, Patancheru, India.

Pande, S. 1998. Diseases of chickpea in Nepal and Bangladesh - A Survey Report, 3 pp (Limited circulation). ICRISAT, Patancheru, AP, India.

Pande, S, J Galloway, PM Gaur, KHM Siddique, HS Tripathi, P Taylor, MJ MacLeod, AK Basandrai, A Bakr, S Joshi, GK Kishore, DA Isenegger, JN Rao, and M Sharma. 2006. Botrytis grey mould of chickpea. a review of biology, epidemiology, and disease management. Aust. J. Agric. Res. 57. 1137-1150.

Pande, S, G Singh, JN Rao, MA Bakr, PCP Chaurasia, S Joshi, C Johansen, SD Singh, J Kumar, MM Rahman, CLL Gowda.2002. Integrated management of botrytis gray mold of chickpea. Information Bulletin No. 61. ICRISAT, Patancheru, AP, India.

Pandey, S and JN Rao. 2000. Integrated management of chickpea in the rice based cropping systems of Nepal. In Program report of the ICRISAT and NARC (Nepal Agricultural Research Council, Khumaltar). Collaborative work in farmer's participatory on-farm trials on the 
validation of improved production practices in seven villages of five districts in Nepal, 29 October 1999-30 April 2000. ICRISAT, Patancheru, AP, India.

Reddy, MV, AM Ghanekar, YL Nene, MP Haware, HS Tripathi and YPS Rathi.1993. Effect of vinclozolin spray, plant growth habitant inter row spacing son botrytis gray mold and yield of chickpea . Indian Journal of Plant.

Reddy, MV, O Singh, MP Barathi, and S Joshi. 1988. Botrytis gray mold epiphytic of chickpea in Nepal. International Chickpea Newsletter 19.15.

Ren, L, S Su, X Yang, Y Xu, Q Huang, and Q Shen. 2008. Intercropping with aerobic rice suppressed Fusarium wilt in watermelon. Soil Biology \& Biochemistry 40. 834-844.

Saxena, NP and C Johansen.1997. Integrated management of botrytis gray mold of chickpea. agronomic and physiological factors. Pages 21-28 in 'Recent advances in research on Botrytis gray mold of chickpea'. (eds. MP Haware, JM Lenne, CLL Gowda). ICRISAT, Patancheru, AP, India.

Shaner, G and RE Finney. 1977. The effect of nitrogen fertilization on the expression of slow mildewing resistance in Knox wheat. Phytopathology 67.1051-1056.

Singh, G. 1997. Epidemiology of botrytis gray mold of chickpea. Pages 47-50 in 'Recent advances in research on botrytis gray mold of chickpea'. (eds. MP Haware, JM Lenné, and CLL Gowda). ICRISAT, Patancheru, AP, India.

Singh, G. 1999. Proposed rating scale for BG of chickpea. BG Newsletter 2 (1). 5-6.

Singh, G and S Kapoor. 1984. Role of incubation and photoperiod on the intensity of botrytis gray mold of chickpea. International Chickpea Newsletter 12. 23-24.

Shrivastav, SP, CR Yadav, TJ Rego, C. Johansen, N.P. Saxena and A. Rama Krishna. 1996. Diagnosis of boron deficiency as a cause of flower abortion and failure of pod set in chickpea in Nepal. International Chickpea and Pigeonpea Newsletter 3.29-30.

Tripathi, HS and YPS Rathi.1992. Epidemiology of botrytis gray mold of chickpea. Pages 8-9 in 'Botrytis gray mold of chickpea'. (eds. MP Haware, DG Faris, CLL Gowda). ICRISAT, Patancheru, AP, India.

Yu, JQ. 1999. Allelopathic suppression of Pseudomonas solanacearum infection of tomato (Lycopersicon esculentum) in a tomato-Chinese chive (Allium tuberosum) intercropping system. Journal of Chemical Ecology, 25 (11)

Zewde, T, C Fininsa, PK Sakhuja, S Ahmed. 2007. Association of white rot (Sclerotium cepivorum) of garlic with environmental factors and cultural practices in the North Shewa highlands of Ethiopia. Crop Prot. 26. 1566-1573. 